\title{
Synthesis, Characterization and Antimicrobial studies of N-tert-amyl acrylamide (NTA) and 7-methacryloyloxy-4- methylcoumarin (MACU) Copolymers
}

\author{
S. Anbarasan ${ }^{1}$, P. Vimala ${ }^{1}$ and P. Pazhanisamy ${ }^{3 *}$ \\ ${ }^{1}$ Department of Chemistry, Thiru. A.Govindasamy Govt.Arts College, Affiliated to Thiruvalluvar \\ University, Tindivanum,-604307, TamilNadu, India \\ ${ }^{2}$ Department of Chemistry, Muthurangam Government Arts College, Affiliated to \\ Thiruvalluvar University, Vellore, Tamil Nadu, India \\ ${ }^{3}$ Department of Chemistry, Sir Theagaraya College, Affiliated to University of Madras \\ Chennai-600021, Tamil Nadu, India \\ E-mail:p_pazhanisamy@yahoo.com
}

\begin{abstract}
Copolymers of N-tert-amylacrylamide (NTA) and 7-methacryloyloxy-4-methylcoumarin (MACU) were prepared by free radical polymerization in DMF at $60^{\circ} \mathrm{C}$ using AIBN as an initiator. The copolymer compositions were determined by $1 H-N M R$ analysis. The reactivity ratios of monomers were determined by Fineman-Ross $(F R)\left(r 1=1.33\right.$ and $\left.r_{2}=0.60\right)$, KelenTudos $(K T)\left(r 1=1.33\right.$ and $\left.r_{2}=0.59\right)$. The $r_{1} . r_{2}=0.798$ indicated the formation of random copolymers. $T_{g}$ found to increasing feed content of MACU. The antimicrobial studies showed that the copolymers are active against both Bacteria and Fungi.
\end{abstract}

Keywords: $\quad$-tert-amyl acrylamide, 7-methacryloyloxy-4-methylcoumarin, reactivity ratios, copolymer composition.

\section{Introduction}

The determination of copolymer composition and reactivity ratios of the monomers is important in evaluating the specific application of copolymer [1]. The monomer reactivity ratios determined by conventional linearization methods are not always accurate and several non-linear methods have been attempted to determine their [2-4]. ${ }^{1} \mathrm{H}-\mathrm{NMR}$ spectroscopic analysis has been established as a powerful tool for the estimation of copolymer composition $[5,6]$. Knowledge of the copolymer composition is an important step in the evaluation of its utility. Copolymer composition and monomer distribution in the copolymer are dependent on the reactivity ratios. The most common mathematical model of copolymerization is based on finding the relationship between the composition of copolymers and the composition of the monomer feed in which the monomer reactivity ratios are the parameters to be determined [7].

The accurate estimation of copolymer composition and determination of monomer reactivity ratios are significant for tailor-made copolymers with required physical and chemical properties and in evaluating the specific and application of the copolymers. The present article reports the synthesis and characterization of copolymers of N-tert-amylacrylamide with 7- 
methacryloyloxy-4-methylcoumarin. The synthesis of antimicrobial polymers is one of the leading frontiers of research in polymer science. With this view our work N-tert-amyl acrylamide was copolymerized with 7-methacryloyloxy-4-methylcoumarin with different feed ratio were prepared and characterized by ${ }^{1} \mathrm{H}-\mathrm{NMR}$ spectroscopy. The reactivity ratios of monomers were determined by Fineman-Ross (FR), Kelen-Tudos (KT) methods. The $r_{1}$ and $r_{2}$ value indicates the formation of random copolymers.

\section{Experimental}

\section{Preparation of N-tert-amylacrylamide (NTA)}

The monomer N-tert-amylacrylamide was prepared by the reaction of tert-amyl alcohol with acrylonitrile. $\mathrm{N}$-tert-amylacrylamide was recrystallized in warm dry benzene. The white crystals have amp. $91^{\circ} \mathrm{C}$ (Lit.91-92 $\mathrm{C}$ ) and the yield was $-87 \%$. The monomer was confirmed by both ${ }^{1} \mathrm{H}$ - NMR and ${ }^{13} \mathrm{C}-\mathrm{NMR}$.

\section{Copolymerization of NTA and MACU}

Copolymers of N-tert-amylacrylamide (NTA) and 7-methacryloyloxy-4-methylcoumarin (MACU) were prepared by free radical polymerization in $\mathrm{DMF}$ at $60^{\circ} \mathrm{C}$ using $\mathrm{AIBN}$ as an initiator. (Scheme 1).

\section{Characterization of copolymer spectra of Poly (NTA-co- MACU)}

The ${ }^{1} \mathrm{H}-\mathrm{NMR}$ spectra of copolymer, poly (NTA-co-MACU) is shown in Figure:1 and the following peaks appear in the copolymer spectrum : at 1.14-2.96 ppm for $\mathrm{CH}_{2}$ group and $\mathrm{CH}_{3}$ of MACU at 3.08ppm for backbone $\mathrm{CH}_{2}$, at 7.07-8.01 ppm due to MACU aromatic protons.

\section{Determination of copolymer composition of Poly (NTA-co- MACU)}

The copolymer composition was determined by ${ }^{1} \mathrm{H}-\mathrm{NMR}$ spectral analysis of the copolymer. The coumarin acrylate area is used to determine the copolymer composition. Resonance signal at $6.8-7.7 \mathrm{ppm}$ corresponds to aromatic proton, and their integrated intensity of this peak is compared to the total intensities of all the peaks in the copolymer spectrum, which is a measure of their relative areas. The copolymer compositions can be obtained using

$$
\mathrm{X}_{\mathrm{MACU}}=\frac{15 \mathrm{~A}(\operatorname{aryl})}{3 \mathrm{~A}_{\text {total }}+3 \mathrm{~A}(\operatorname{aryl})}
$$

Where $\mathrm{X}=$ mole fraction and $\mathrm{A}=$ peak area.

\section{Determination of Reactivity ratios}

The reactivity ratios for NTA $\left(r_{1}\right)$ and MACU $\left(r_{2}\right)$ value from the F-R plot (Figure 2) K-T plot (Figure 3) are given in Table 3. The value(s) of $r_{1}$ is greater than 1 and $r_{2}$ is less than 1 .The $r_{1}$ shows that NTA favors homo-propagation as opposed to cross propagation and $\mathbf{r}_{2}$ shows that MACU favors cross propagation over homo-propagation. The $r_{1}$ and $r_{2}$ together shows that NTA is generally more reactive than MACU, hence the copolymer contains a higher proportion of NTA units. The product of $r_{1} \cdot r_{2}=0.79$ value indicates that the copolymers are weakly ordered and predominantly a random distribution of monomeric unit in the polymer chain. 


\section{Thermal studies of poly (NTA-co- MACU)}

The thermal behaviors of poly (NTA-co-MACU) values are given in Table-4. Thermal behaviors of polymers were studied using TG and DSC traces. The thermo grams of poly (NTA-co-MACU) show three stage decomposition. The initial weight loss observed is due to moisture content. Weight loss at stage- 1 is associated with scission of amide groups; Weight loss at stage- 2 can be related to possible decarboxylation and/or other reactions of side-chain units. The stage- 3 weight loss indicates the main-chain degradation reactions and breakdown of the polymer backbone.

\section{Antimicrobial Activity of poly (NTA-co- MACU)}

Antimicrobial analysis was carried out by well diffusion method [8-10] against various bacteria and fungi. Antimicrobial activity was evaluated by measuring the diameter of the zone of inhibition in against the test microorganisms. DMSO was used as solvent control. Chloramphenicol is used as reference antibacterial agent. Amphotericin B is used as reference antifungal agent. It is observed from the results that both antibacterial and antifungal activity is maximum. The inhibiting activity is found to be more than that of the standard. The antimicrobial activities are shown in Figure 4 and 5 and the zone of inhibition values are given in Table-5 and 6. It also showed good antimicrobial activities against selected microorganism. The antibacterial and antifungal activities are found to be more than the Chloramphenicol Amphotericin Drugs

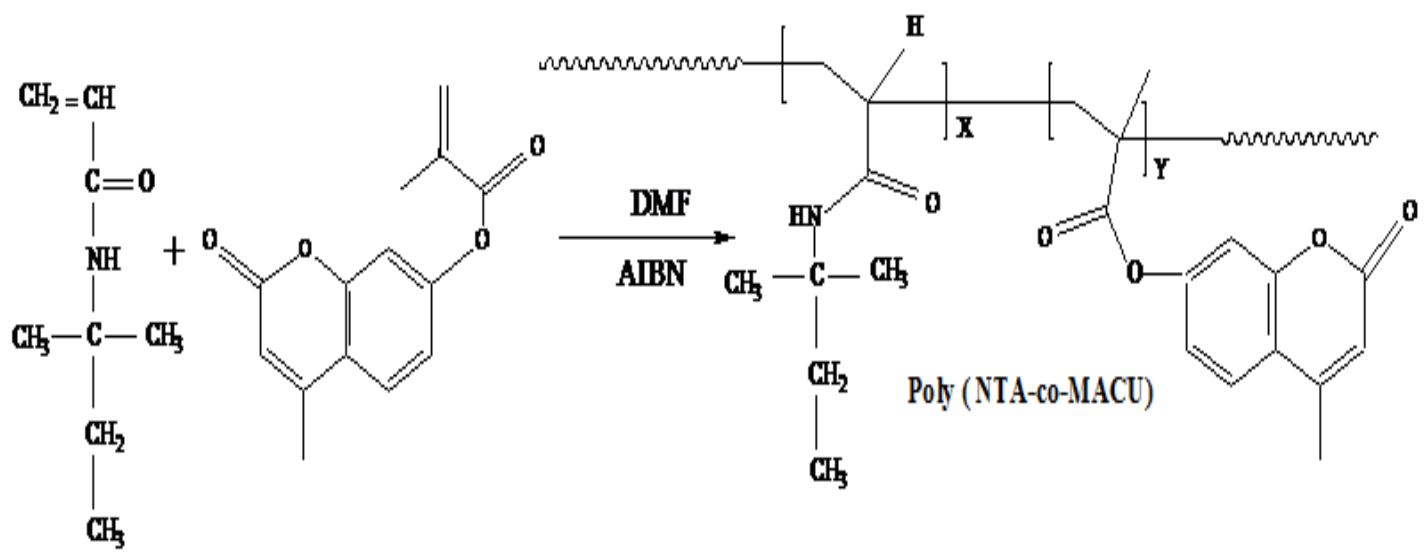

Scheme 1: Copolymerization of NTA and MACU 


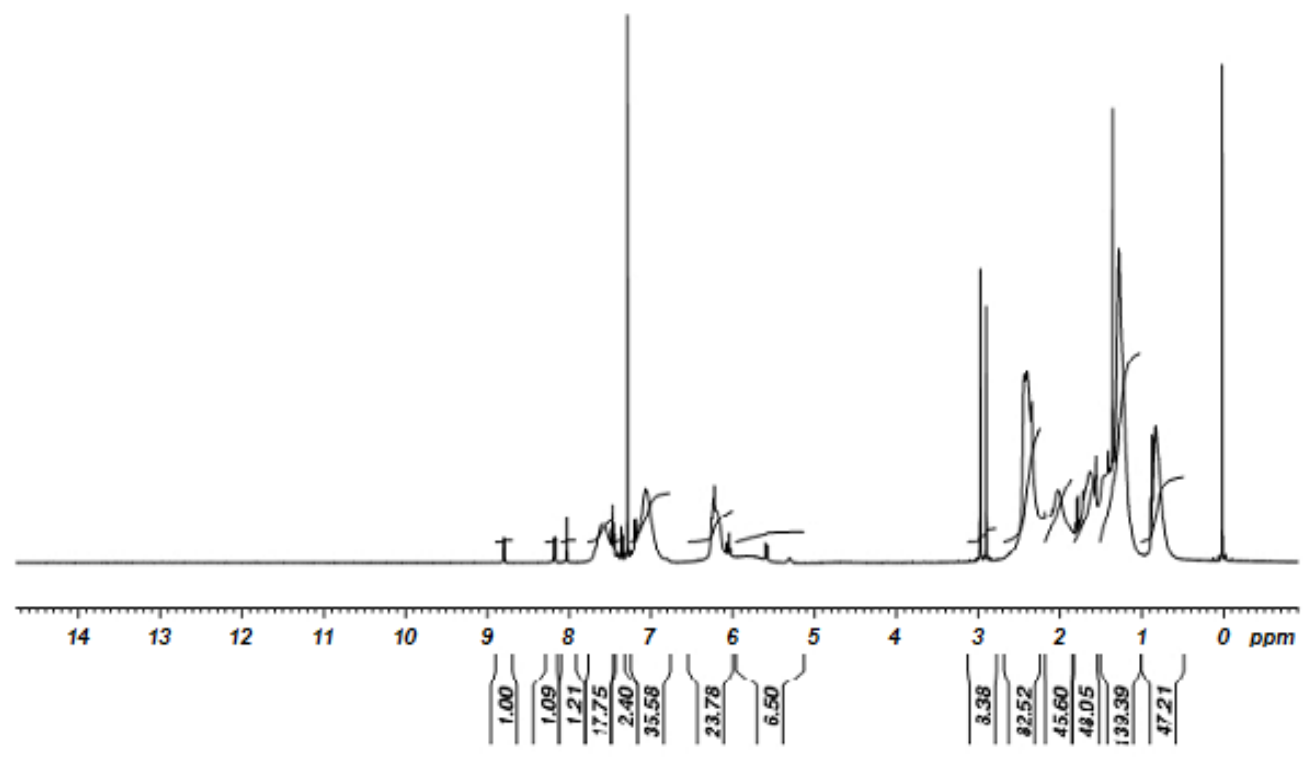

Figure 1: ${ }^{1} \mathrm{H}-\mathrm{NMR}$ spectrum of poly (NTA-co- MACU) (a) 0.5:0.5

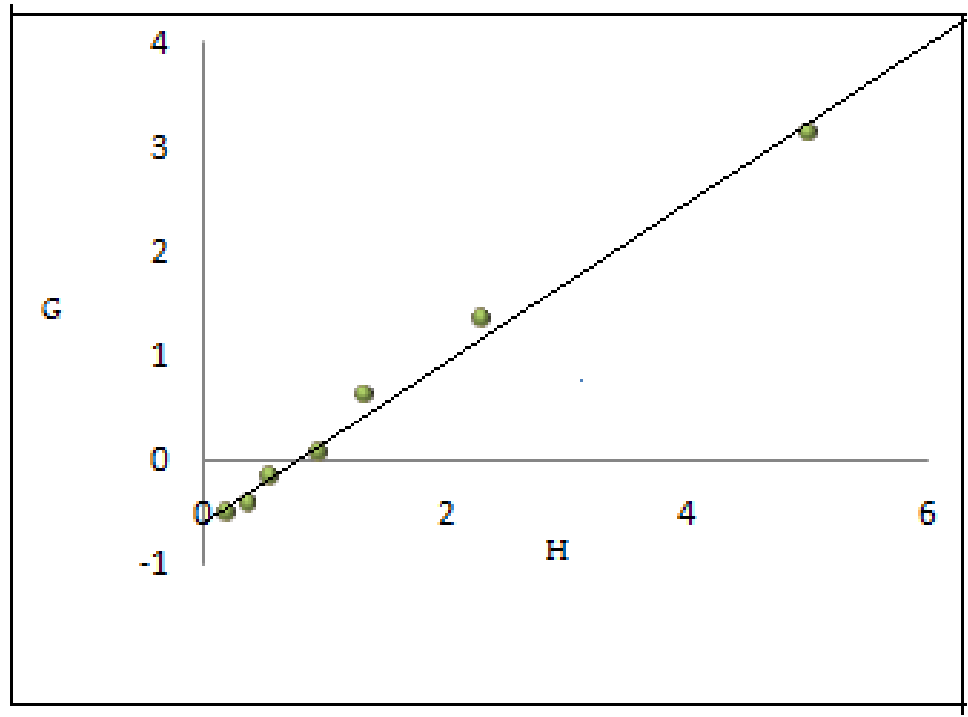

Figure 2: Fineman-Ross plot for Poly (NTA-co- MACU) 


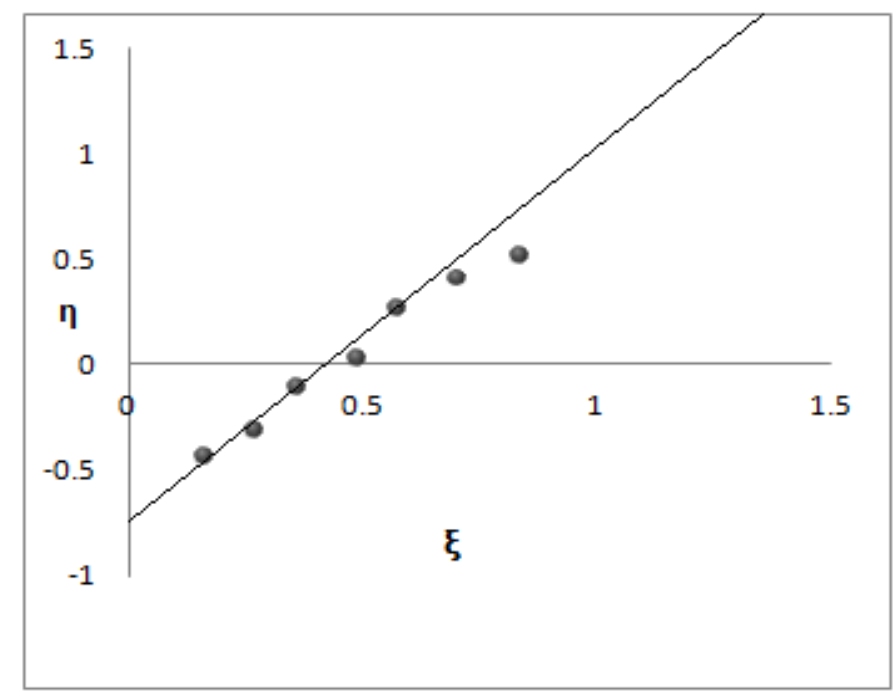

Figure 3: Kelen-Tudos plot for Poly (NTA-co- MACU)

Table 1: Mole fractions of the copolymers of $\mathrm{N}$-tert-amylylacrylamide (NTA) and (MACU)

\begin{tabular}{|l|l|l|l|l|l|}
\hline $\begin{array}{l}\text { Mole } \\
\text { fraction of } \\
\text { NTA in } \\
\text { feed, M1 }\end{array}$ & $\begin{array}{l}\text { Mole } \\
\text { fraction of } \\
\text { MACU in } \\
\text { feed, M2 }\end{array}$ & $\begin{array}{l}\text { Mole fraction } \\
\text { of NTA in } \\
\text { copolymer,m1 }\end{array}$ & $\begin{array}{l}\text { Mole fraction } \\
\text { of MACU in } \\
\text { copolymer, } \\
\text { M2 }\end{array}$ & $\begin{array}{l}\text { F= } \\
\text { M1/M2 }\end{array}$ & F=m1/ m2 \\
\hline 0.2 & 0.8 & 0.2467 & 0.7533 & 0.2500 & 0.3275 \\
\hline 0.3 & 0.7 & 0.3343 & 0.6657 & 0.4286 & 0.5022 \\
\hline 0.4 & 0.6 & 0.4452 & 0.5548 & 0.6667 & 0.8025 \\
\hline 0.5 & 0.5 & 0.5134 & 0.4866 & 1.0000 & 1.0551 \\
\hline 0.6 & 0.4 & 0.6276 & 0.3724 & 1.5000 & 1.6853 \\
\hline 0.7 & 0.3 & 0.7023 & 0.2977 & 2.3333 & 2.3591 \\
\hline 0.8 & 0.2 & 0.7615 & 0.2385 & 4.0000 & 3.1929 \\
\hline
\end{tabular}

Table 2: Fineman-Ross and Kelen - Tudos parameters for the Copolymers of NTA and MACU

\begin{tabular}{|c|c|c|c|}
\hline $\mathbf{G}=\mathbf{F}(\mathbf{f}-\mathbf{1}) / \mathbf{f}$ & $\mathbf{H}=\mathbf{F}^{2} / \mathbf{f}$ & $\boldsymbol{\eta}=\mathbf{G} /(\boldsymbol{\alpha}+\mathbf{H})$ & $\xi=\mathbf{H} /(\boldsymbol{\alpha}+\mathbf{H})$ \\
\hline-0.5134 & 0.1908 & -0.4357 & 0.1620 \\
\hline-0.4252 & 0.3665 & -0.3141 & 0.2707 \\
\hline-0.1642 & 0.5544 & -0.1065 & 0.3595 \\
\hline 0.0522 & 0.9478 & 0.0270 & 0.4897 \\
\hline 0.6100 & 1.3351 & 0.2626 & 0.5748 \\
\hline 1.3441 & 2.3072 & 0.4079 & 0.7003 \\
\hline 3.1200 & 5.0111 & 0.5201 & 0.8354 \\
\hline
\end{tabular}

$\alpha=0.98$ 
Table 3: Reactivity ratios of NTA (r $\left.\mathbf{r}_{1}\right)$ and MACU ( $\left.\mathbf{r}_{2}\right)$

\begin{tabular}{|l|c|c|c|}
\hline \multicolumn{1}{|c|}{ Methods } & $\mathbf{r}_{1}$ & $\mathbf{r}_{2}$ & $\mathbf{r}_{1 . r_{2}}$ \\
\hline Fineman-Ross (FR) & 1.33 & 0.600 & 0.798 \\
\hline Kelen-Tudos (KT) & 1.33 & 0.596 & 0.793 \\
\hline
\end{tabular}

Table 4: TGA data for Poly (NTA-co- MACU)

\begin{tabular}{|c|c|c|c|c|c|c|c|}
\hline Copolymers & $\begin{array}{c}\text { Mole } \\
\text { fraction of } \\
\text { NTA, in } \\
\text { feed }\end{array}$ & $\begin{array}{c}\text { Mole } \\
\text { fraction of } \\
\text { 8-MACU, } \\
\text { in feed }\end{array}$ & $\begin{array}{c}\text { Mole } \\
\text { fraction of } \\
\text { MACU, in } \\
\text { copolymer }\end{array}$ & $\begin{array}{c}\text { IDT } \\
\left({ }^{\circ} \mathbf{C}\right)\end{array}$ & $\begin{array}{c}\mathbf{T}_{50} \\
\left({ }^{\circ} \mathbf{C}\right)\end{array}$ & $\begin{array}{c}\mathbf{T}_{\mathbf{f}} \\
\left({ }^{\circ} \mathbf{C}\right)\end{array}$ & $\begin{array}{c}\mathbf{T}_{\mathbf{g}} \\
\left({ }^{\circ} \mathbf{C}\right)\end{array}$ \\
\hline $\begin{array}{c}\text { NTA- } \\
\text { MACU }\end{array}$ & 0.70 & 0.30 & 0.2977 & 128 & 316 & 610 & 129 \\
\hline $\begin{array}{c}\text { NTA- } \\
\text { MACU }\end{array}$ & 0.50 & 0.50 & 0.4866 & 135 & 350 & 622 & 135 \\
\hline $\begin{array}{c}\text { NTA- } \\
\text { MACU }\end{array}$ & 0.30 & 0.70 & $0 . .6657$ & 138 & 355 & 677 & 144 \\
\hline Poly-NTA & & - & - & - & - & & 86.2 \\
\hline
\end{tabular}

IDT: Initial Decomposition Temperature

$\mathrm{T}_{50}$ : decomposition temperature at $50 \%$ weight loss

$\mathrm{T}_{\mathrm{f}}$ : final decomposition temperature

$\mathrm{T}_{\mathrm{g}}$ : glass transition temperature

Table 5: Anti-bacterial activity of poly (NTA-co- MACU)

\begin{tabular}{|c|c|c|c|c|}
\hline S.No & Copolymers & $\begin{array}{c}\text { Staphylococcus } \\
\text { aureus }\end{array}$ & $\begin{array}{c}\text { Escherichia } \\
\text { coli }\end{array}$ & $\begin{array}{c}\text { Pseudomonas } \\
\text { aeruginosa }\end{array}$ \\
\hline $\mathbf{1}$ & 0.3 NTA:0.7 MACU & 30 & 10 & No zone \\
\hline $\mathbf{2}$ & 0.5 NTA:0.5MACU & 26 & 6 & No zone \\
\hline $\mathbf{3}$ & 0.7 NTA:0.3 MACU & 14 & 6 & No zone \\
\hline $\mathbf{4}$ & Chloramphenicol & 26 & 28 & 10 \\
\hline
\end{tabular}

Table 6: Anti-fungal activity of poly (NTA-co- MACU )

\begin{tabular}{|c|l|c|c|c|}
\hline S.No & \multicolumn{1}{|c|}{ Compounds } & $\begin{array}{c}\text { Aspergillus } \\
\text { niger }\end{array}$ & $\begin{array}{c}\text { Candida } \\
\text { albicans }\end{array}$ & $\begin{array}{c}\text { Candida } \\
\text { tropicalis }\end{array}$ \\
\hline $\mathbf{1}$ & 0.3 NTA:0.7 MACU & 40 & 27 & 31 \\
\hline $\mathbf{2}$ & 0.5 NTA:0.5MACU & 40 & 22 & 23 \\
\hline $\mathbf{3}$ & 0.7 NTA:0.3 MACU & 13 & 8 & 12 \\
\hline $\mathbf{4}$ & Amphotericin B & 16 & 14 & 19 \\
\hline
\end{tabular}




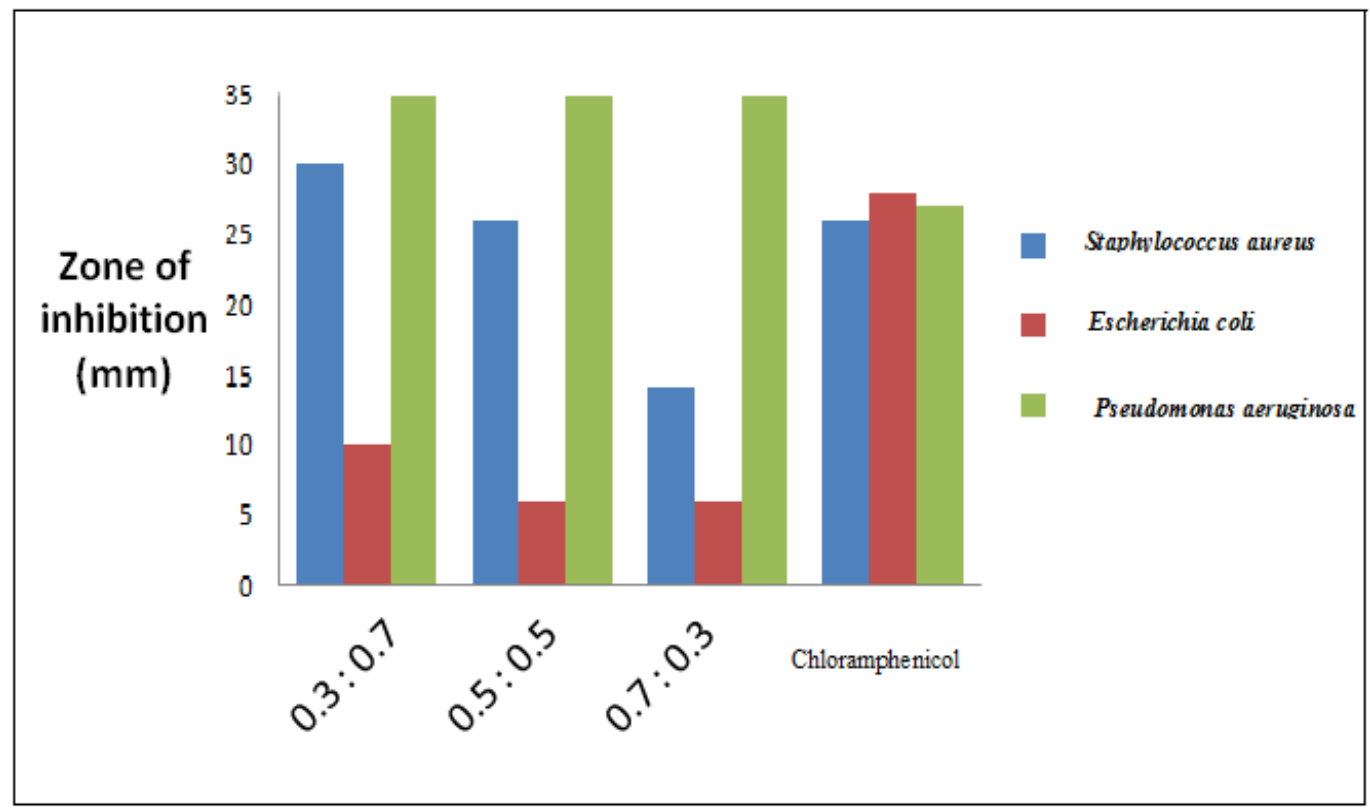

Figure 4: Comparison of Zone of inhibition of Poly (NTA-co- MACU) with bacteria

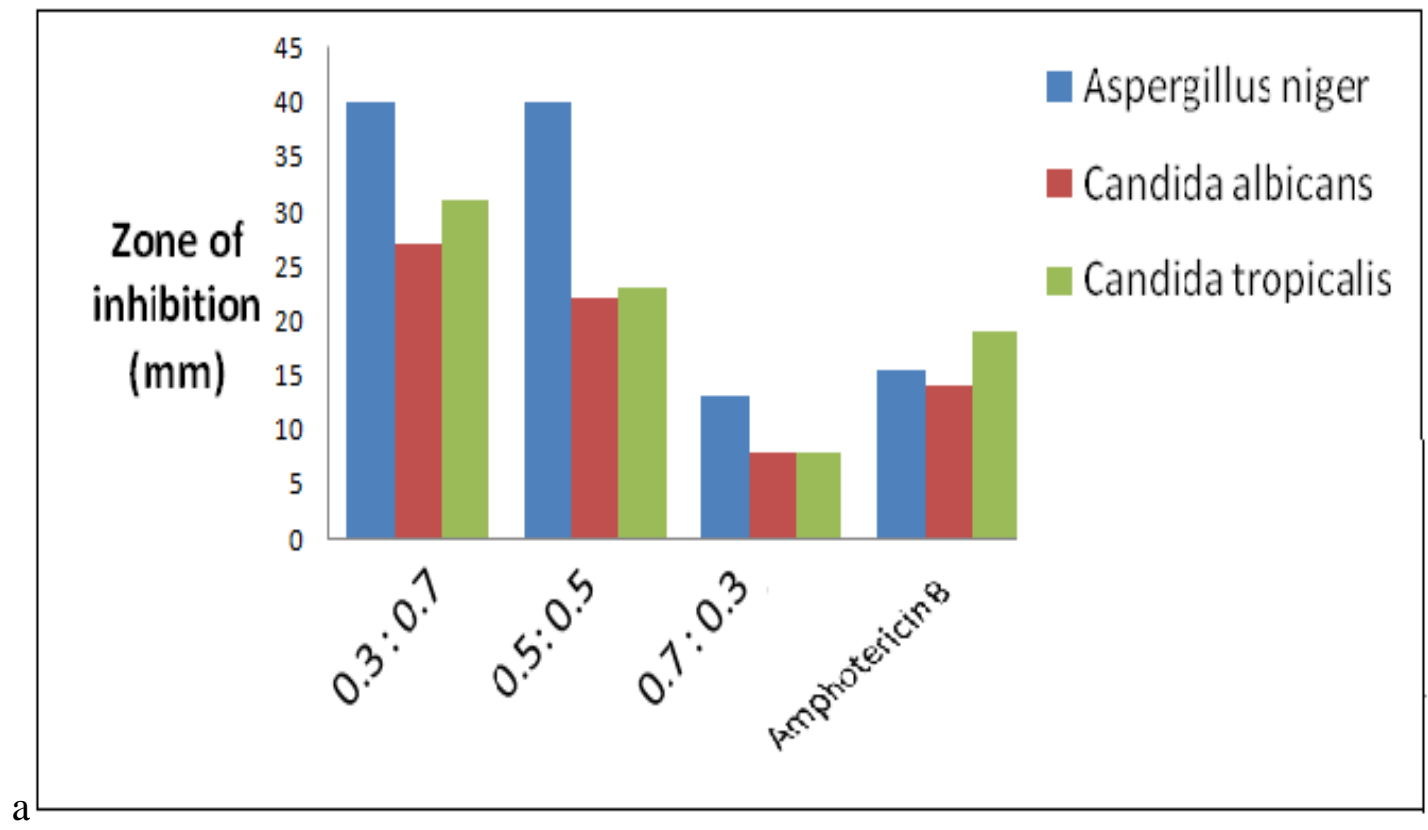

Figure 5 : Comparison of Zone of inhibition of Poly (NTA-co- MACU )with fungi 


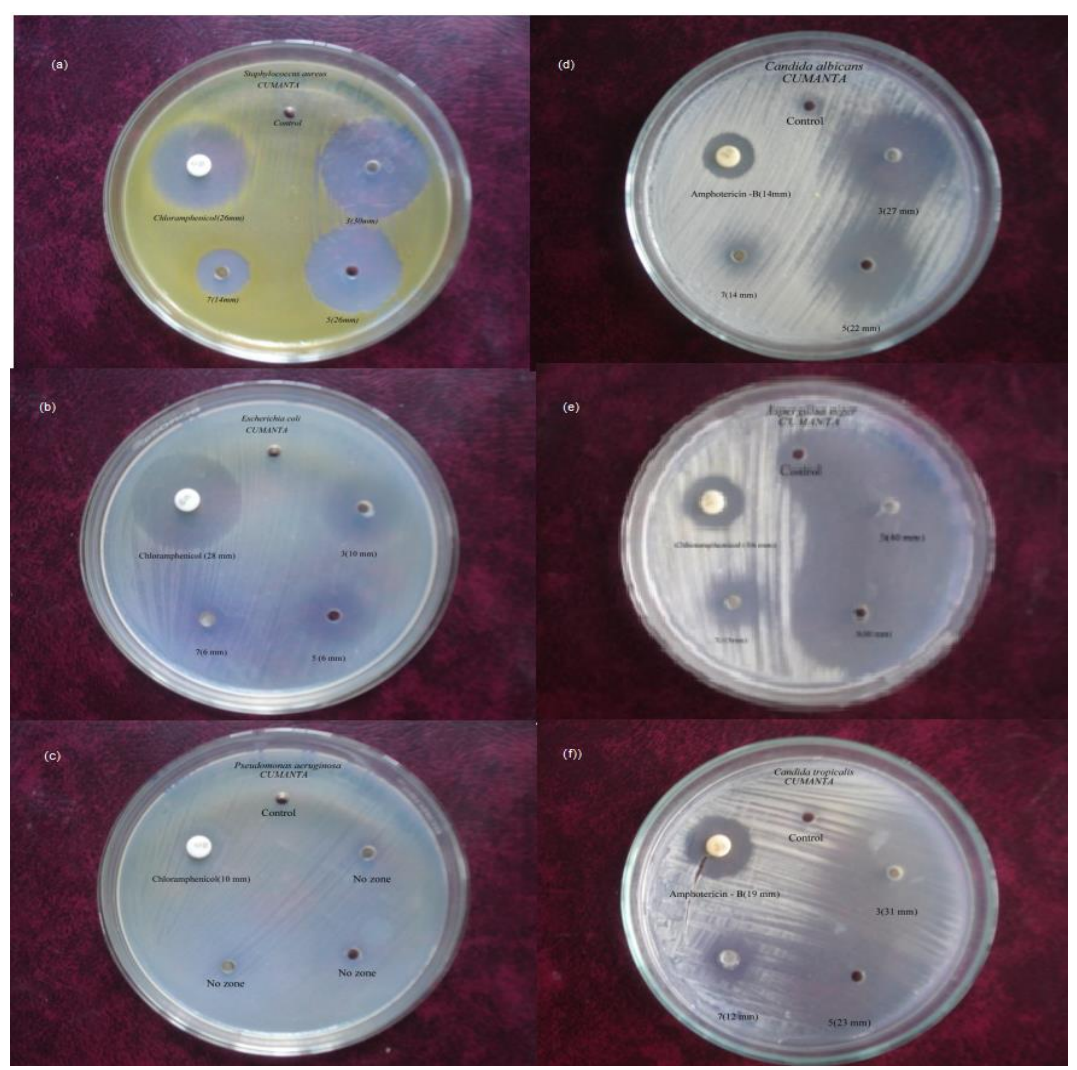

Figure 6: Antimicrobial studies of Poly (NTA-co- MACU)

\section{Conclusions}

Copolymers of N-tert-amylacrylamide (NTA) and 7-methacryloyloxy-4-methylcoumarin (MACU) were prepared by free radical polymerization. The copolymer compositions were determined by ${ }^{1} \mathrm{H}-\mathrm{NMR}$ analysis. The reactivity ratios of monomers $)\left(\mathrm{r} 1=1.33\right.$ and $\left.\mathrm{r}_{2}=0.60\right)$,) $\left(\mathrm{r} 1=1.33\right.$ and $\left.\mathrm{r}_{2}=0.59\right)$. Were determined by Fineman-Ross $(\mathrm{FR})$ Kelen-Tudos $(\mathrm{KT})$ respectively, The $r_{1} \cdot r_{2}=0.798$ indicated the formation of random copolymers. $T_{g}$ found to increasing feed content of MACU. The antimicrobial studies showed that the copolymers are active against both Bacteria and Fungi.

\section{REFERENCES}

[1] S.pitchumani, B.S.Rami Reddy and C. Rajadurai, Journal of Polymer Science: Polymer Chemistry Edition,20, 277(1982).

[2] M. Dube, R.A. Sanayei, A. Penlids, K.F. O' Driscoll and P.M. Reilly, Journal of Polymer Science, 29,703(1991).

[3] A.L.Polic, T.A Duever and A. Penlidis,Journal of Polymer Science Part A: polymerchemistry,36, 813 (1998).

[4] C. Hagiopol, O. Frangu and L. Dumitru, Journal of Macromolecular Science Chemistry Edition, 26, 1363 (1989).

[5] P. Pazhanisamy, M. Ariff and Q. Anwaruddin, Journal of Macromolecular Science: Pure and Applied Chemistry, 34, 1045 (1997). 
[6] P. Pazhanisamy, P. Sulochana, Q. Anwaruddin and M. Ariff, Journal of Polymer Science parta: Polymer Chemistry, 35, 193 (1997).

[7] R. Arshady, G.W.Kenner and A.W. Led, Journal of Polymer Science Polymer Chemistry Edition, 12 (9), 2017 (1974)

[8] Hetal Patel, Mitesh Patel, Kirit Patel and Rajni Patel, e-Polymers, 125 1-11( 2007).

[9] M.Fineman and S. D.Ross, J.Polym.Soc., 5,259 (1950).

[10] T.Kelen and F.Tudos, React.Kinet.Catal.Lett., 1(4) , 487 (1974).

[11] T.Kelen and F.Tudos, J.Macromol.Sci.Chem., A9, 1 (1975). 